\author{
Dr. sc. Ratko Brnabić, docent \\ Pravnog fakulteta Sveučilišta u Splitu, \\ Bojan Brkić \\ student Pravnog fakulteta Sveučilišta u Splitu
}

\title{
ISTUP ČLANA DRUŠTVA S OGRANIČENOM ODGOVORNOŠĆU
}

\begin{abstract}
UDK: $347.7(497.5)$
Primljeno: 10. 10. 2016.

Pregledni rad

Istup člana iz društva je pravno sredstvo koje je zakonodavac stavio na raspolaganje članovima društva s ograničenom odgovornošću, a riječ je o dobrovoljnom izlasku iz društva što za posljedicu ima prestanak članstva. Tim sredstvom oni se ne mogu koristiti bez ograničenja. Naime, istupom člana mijenjaju se članski odnosi u društvu, a društvo je članu dužno isplatiti i naknadu za njegov poslovni udio što može utjecati na sposobnost društva za podmirivanje svojih obveza. Stoga se istup može dopustiti samo pod pretpostavkama uređenima Zakonom, u suprotnom bi pravo na istup predstavljalo sredstvo zlouporabe prava. U tom smislu, posebnu pozornost pobuđuje pojam opravdanog razloga za istup člana i njegov sadržaj treba utvrditi i izvan okvira zakonske odredbe koja ga uređuje. Članovi mogu svojim pravima raspolagati i na drugi način pa tako mogu svoje poslovne udjele u društvu prenijeti na treće. U praksi se, međutim, pokazalo da se u društvene ugovore nerijetko unose odredbe o vinkulaciji poslovnih udjela pa je tada potrebno za prijenos dobiti odobrenje društva. Nadalje, kod poduzetničkih ugovora, kod priključenja kao i kod statusnih promjena član ima zakonom uređeno pravo na istup iz društva. Pored prava na istup, manjinski članovi zbog opravdanog razloga imaju pravo tužbom zahtijevati prestanak društva. U radu će biti više riječi o pretpostavkama za istup, postupku istupa kao i njegovim pravnim učincima. Na kraju se donose izvorni zaključci o pravnoj naravi tog instituta.
\end{abstract}

Ključne riječi: istup, isključenje, povlačenje poslovnog udjela, naknada, društva kapitala

\section{UVOD}

Pitanje istupa člana iz društva s ograničenom odgovornošću spada u teme koje u praksi izazivaju dvojbe. Na prvi pogled moglo bi se zaključiti da član uvijek smije istupiti iz društva, kao što je slobodnom voljom postao i članom društva. Istup se razlikuje od isključenja jer je tu riječ o dobrovoljnom postupanju člana koji zbog određenih razloga ne želi i dalje ostati članom društva. Međutim, pravo člana na istup stavlja se u drugi plan jer je kod d.o.o.-a osnovno polazište da član može „,istupiti“ iz društva prijenosom svog poslovnog udjela na treće osobe. Pri tome se zanemaruje činjenica da je u praksi takvo raspolaganje otežano zbog konkretnih 
okolnosti kao što je okolnost nepostojanja uređenog tržišta za trgovinu poslovnim udjelima ili okolnost da se društvo u većoj mjeri temelji na osobnim odnosima članova a ne toliko na kapitalu. Vrijedi pripomenuti da je upravo fleksibilnost ustroja d.o.o.-a jedan od glavnih razloga za popularnost tog tipa društva.

Nesporno je da prema temeljnim načelima trgovačkog statusnog prava koje je kod nas pretočeno u zakonske odredbe (čl. 420. i 421. Zakona o trgovačkim društvima, u nastavku: ZTD) član društva ima pravo na istup iz društva čak i onda kada to nije posebno uređeno u društvenom ugovoru što znači da načelno može tako postupiti suprotno volji ostalih članova. ${ }^{1}$ Pravo člana na istup uređeno je i odredbom čl. 492. ZTD-a u svezi sa sklapanjem ugovora o vođenju poslova društva i/ili ugovora o prijenosu dobiti, odredbom čl. 504. i 504.a ZTD-a kod priključenja odlukom većine, te kod statusnih promjena (čl. 550.j i 550.k ZTD-a). Pravo na istup jest neotuđivo osobno pravo svakog člana koje proizlazi i iz općeg pravnog načela da se svaki trajniji pravni odnos može okončati ako za to postoji opravdan razlog. Zbog toga spomenuto pravo nije moguće isključiti ili ograničiti već samo proširiti. To se može provesti tako da se društvenim ugovorom urede pretpostavke koje članu daju pravo na istup zbog važnog razloga no nema prepreke da se društvenim ugovorom članovima omogući i redovito pravo na istup (bez postojanja važnog razloga). Jasno je da član može istupiti iz društva uvijek kad se s tim složi skupština društva iako za to u konkretnom slučaju nije postojao važan razlog niti je pravo na redoviti istup uređeno društvenim ugovorom (iako o tome postoje i suprotna mišljenja, o čemu će biti više riječi kasnije u radu). Jedina pretpostavka koja se tada mora ispuniti jest da istupom člana iz društva nisu ugroženi interesi vjerovnika. Naime, isticanje opravdanog razloga za istup zakonska je pretpostavka koja služi zaštiti interesa ostalih članova. Odreknu li se ostali članovi te zaštite, član može istupiti iz društva, a oni će to odobrenje dati odgovarajućom odlukom na skupštini društva. ${ }^{2}$ Ta odluka mora potpuno jasno i nedvojbeno ukazivati na to da se članu daje odobrenje pa se tako ne smatra odobrenjem ako se na skupštini donese zaključak da je izjava $o$ istupu primljena na znanje. ${ }^{3}$

Dvojbeno je, međutim, mora li za istup uvijek biti ispunjena pretpostavka da postoji opravdan razlog ili je dopustivo da se članovima društva da pravo na istup kao redovito pravo kojim se mogu koristiti i kad nije nastao opravdan razlog već su se ispunile neke druge pretpostavke. ${ }^{4}$ Neki autori zauzimaju polazište da redovito

Zakon o trgovačkim društvima (Narodne novine 111/1993, 34/1999, 121/1999, 52/2000, 118/2003, 146/2008, 111/2012, 125/2011, 68/2013, 110/2015).

2 Nije ispravno polazište koje zauzima njemački Vrhovni sud (BGH) u presudi od 30. XI. 2009. - Az. II ZR 208/08, dostupnoj na https://openjur.de/u/70895.html, pregledano 12. IX. 2016. U presudi se navodi da je za istup dostatno da ga odobri društvo što znači da odobrenje zapravo daje uprava a ne skupština.

3 Vidi presudu njemačkog Vrhovnog suda od 18. II. 2014. - II ZR 174/11, dostupnu na https:// openjur.de/u/685799.html, pregledano 12. IX. 2016.

${ }^{4}$ O pitanju opravdanog razloga za istup u njemačkoj literaturi i sudskoj praksi raspravlja se od početka 20. stoljeća. Njemački Zakon o d.o.o.-u nema odredbe koje bi odgovarale odredbama iz 420. i 421. našeg ZTD-a no ta je ,,praznina“" popunjena sudskom praksom i doktrinom. To posebice u kontekstu odredbe o vinkulaciji poslovnih udjela. Naime, u konkretnom slučaju zamislivo je da društvo ne odobri prijenos pa član zapravo i ne može raspolagati svojim poslovnim udjelom. Vrhovni sud Njemačkog 
pravo na istup postoji ako se članu osobno nametnu dodatne obveze koje mora ispuniti prema društvu. Dio autora smatra da član ima redovito pravo na istup kada je njegovo pravo raspolaganja poslovnim udjelom ograničeno ili isključeno zbog vinkulacije poslovnih udjela ili u slučaju kada član zbog stvarnih (konkretnih) prepreka ne može koristiti pravo na prijenos poslovnog udjela. Prema drugačijem polazištu, za istup je dostatno da član ne može pronaći kupca za svoj poslovni udjel u određenom razdoblju pa je taj udjel postao faktički „neprenosiv“. Neki autori pak smatraju da nemaju pravo na istup članovi onih d.o.o.-a kod kojih ne postoji društvenim ugovorom uređeno ograničenje raspolaganja poslovnim udjelima. Ovo posljednje polazište ne može se prihvatiti jer je riječ o osobnom, neotuđivom članskom pravu pa je pitanje o mogućnosti slobodnog raspolaganja udjelom samo indicija koju treba razmatrati s ostalim okolnostima slučaja. ${ }^{5}$ Ipak, prevladavajuće je mišljenje da član može koristiti pravo na izvanredan istup iz društva ako za to postoji opravdan razlog. ${ }^{6}$ Drugačije rješenje bilo bi suprotno pravnom ustroju ovog tipa društva, jer da se htjelo da član može slobodno istupiti iz društva, moglo se jednostavno prepisati odredbu koja uređuje javno trgovačko društvo a prema kojoj član može otkazati društveni ugovor pri čemu društvo može nastaviti s preostalim članovima (čl. 98. i 104. ZTD-a). Također, okolnost da su poslovni udjeli člana vinkulirani nije dostatan razlog za istup, iako bi se na prvi pogled moglo zaključiti da je riječ o ozbiljnom ograničenju za raspolaganje udjelom. Naime, okolnost da član mora dobiti odobrenje društva za prijenos nije nepremostiva prepreka jer društvo ionako mora obrazložiti odluku kojom odbija odobriti prijenos vinkuliranog udjela, a pravo na otuđenje poslovnog udjela može se ostvarivati i sudskim putem. Naposljetku, pitanje mogućnosti raspolaganja udjelom i nije u izravnoj svezi s pitanjem opravdanosti nečijeg daljnjeg ostanka u društvu niti je u svezi s činjenicom da se pravo na istup može koristiti tek onda kada se član prethodno poslužio nekim drugim, po društvo blažim pravnim sredstvom. Drugim riječima, član će pokušati prodati svoj poslovni udjel u društvu nakon što je već nastao opravdan razlog za istup pa će tek tada saznati da mu društvo neće dati suglasnost za prijenos udjela.

Carstva istup dopušta ako član ne može više ispunjavati dodatne obveze pod uvjetom da dodatna obveza uplate nije bila ograničena na određeni iznos. Ostali viši sudovi, a prvenstveno njemački Vrhovni sud (kao nasljednik prvospomenutog Suda) zauzimaju polazište da je izvanredno pravo na istup opći pravni institut. Članu pripada pravo na istup zbog važnog (opravdanog) razloga koji postoji onda kada zbog konkretnih okolnosti više nije opravdano (razumno) očekivati da osoba i dalje bude član društva. Schindler, H., u: Ziemons, H./Jaeger, C., Beck’scher Kommentar GmbHG, 28. Edition, Verlag C.H. Beck, München, 2016. $\S 34$, Rn. 161.

5 Detaljnije o tome vidi Lutter, M., u: Lutter, M. /Hommelhoff, P.,GmbH-Gesetz Kommentar, Verlag Otto Schmidt, Köln, 2012., § 34 Anh. Rn. 72.

6 Röhricht, V., Zum Austritt des Gesellschafters aus der GmbH, FS Alfred Kellermann, Berlin, de Gruyter, 1991., str. 374. i dalje. 


\section{PODRUČJE PRIMJENE ODREDABA O PRAVU ČLANA NA ISTUP IZ DRUŠTVA}

Član smije istupiti iz društva ako za to postoji opravdan razlog bez obzira na to kakav je konkretan ustroj društva, što znači da mu to pravo pripada onda kada je kod ustroja društva naglasak stavljen na osobne odnose članova jednako kao i u slučaju kada je društvo ustrojeno kao tipično društvo kapitala u kojem nije od značaja pitanje tko je član društva. Prije se može očekivati da će doći do sukoba između članova kod obiteljskih d.o.o-a, posebice ako je članski položaj u tim društvima nasljedan, nego kod društava čiji članovi nisu povezani na osobnoj razini.

Pravo na istup postoji i kod dvočlanih društava. U tom slučaju posebno treba ispitati je li opravdano očekivati od jednog preostalog člana da nastavi s društvom ili je bolje rješenje donijeti odluku o prestanku društva. Na članu koji istupa leži teret dokaza da postoji opravdan razlog te je on dužan i dati izjavu da istupa iz društva. Društvo ima pravo na protudokaz tj. ima pravo dokazati da, uzimajući u obzir sve okolnosti, nije nastao opravdan razlog za istup.

Postupak istupa, jednako kao i postupak isključenja člana, moguće je provesti već i u fazi preddruštva jer je društveni ugovor usvojen. ${ }^{7}$ Istup je dopušten i u fazi likvidacije društva, ali se kao opravdan razlog za istup tada ne može isticati okolnost da je društvo promijenilo svoj cilj (okončanje društva i razdioba ostatka likvidacijske mase članovima).

Iako član ima pravo na istup, njegova je dužnost poduzeti sve što je u njegovoj moći da prenese svoj poslovni udio na novog imatelja koji će mu za to isplatiti dogovorenu naknadu. Kod prijenosa udjela nekog d.o.o.-a treba obratiti pozornost na nekoliko činjenica: prvo, ne postoji uređeno tržište za poslovne udjele kao što je to slučaj s dionicama; drugo, prijenos udjela nerijetko je otežan i zbog međusobnog odnosa članova (nesuglasje). Zbog toga ta „teoretska“ mogućnost raspolaganja udjelom ne predstavlja uvijek pravedno rješenje pa se ravnoteža uspostavlja odredbama o pravu člana na istup iz društva. Pravo člana na istup bolje odgovara pravnim odnosima u društvima osoba jer je kod društava kapitala naglasak na poslovnim udjelima a ne na osobi člana. Na tom tragu može se zaključiti da zakonske odredbe o d.o.o.-u zbog svog dispozitivnog karaktera ostavljaju prostor da članovi ustroje svoje društvo kako žele, pa čak da odaberu rješenja koja su karakteristična za društva osoba. Ipak, Zakonodavac za ovaj tip društva nije predvidio redovito pravo članova na istup kakvo postoji kod javnog trgovačkog društva jer bi to bilo suprotno pravnoj prirodi društva s ograničenom odgovornošću. Prihvati li se slobodno pravo članova d.o.o.-a na istup iz društva, tada nema smisla odredba o vinkuliranim poslovnim udjelima jer bi član, u slučaju kada mu društvo zbog opravdanog razloga ne dopusti prijenos udjela, mogao zatražiti istup pa će time prisiliti društvo da mu uvijek odobri (dopusti) prijenos udjela. Zapravo, nema ni potrebe da postoji redovito pravo na istup jer će se članu to pravo priznati uvijek kada za to postoji

Tako Strohn, L., u: Fleischer, H./Goette W., Münchener Kommentar zum Gesetz betreffend die Gesellschaften mit beschränkter Haftung, Verlag C. H. Beck, München, 2016., § 34, Rn. 115. 
opravdan razlog. Primjerice, ako član u društvu ima dodatne obveze (obvezu da vodi poslove društva ili da za njega kao člana vrijedi zabrana konkurencije) a više nije opravdano očekivati da ih ispunjava, to može predstavljati opravdan razlog za istup. Ako član ne može raspolagati svojim poslovnim udjelom, time još nije nastao opravdan razlog za istup. Uostalom, za slučajeve kada ponašanje društva predstavlja zlouporabu, primjerice u slučaju kada društvo članu ne dopusti prijenos udjela iako za to ne postoje prepreke, taj član može ustati tužbom prema društvu i zahtijevati da mu se dopusti prijenos. Zbog svega navedenoga, pravo na istup ne bi smjelo biti redovito pravno sredstvo u rukama člana već bi mu ono pripadalo samo ako je nastao opravdan razlog. ${ }^{8} \mathrm{~S}$ druge strane, redovito pravo na istup može se urediti društvenim ugovorom. Kod istupa, jednako kao i kod isključenja člana, treba voditi računa o zaštiti vjerovnika. Načelno, član može istupiti ako je u cijelosti uplatio ulog, a naknada koja se isplaćuje članu smije se isplatiti samo iz sredstava aktive koja po iznosu prelaze vrijednost temeljnog kapitala društva.

\section{PRETPOSTAVKE ZA ISTUP ČLANA IZ DRUŠTVA}

Za istup člana iz društva moraju se ispuniti tri pretpostavke: prvo, mora postojati opravdan razlog zbog kojeg se više ne može očekivati da član ostane u društvu pri čemu treba uzeti u obzir sve okolnosti slučaja; drugo, ne smije postojati blaže pravno sredstvo kojim član može ostvariti cilj (supsidijarna narav prava na istup) i treće, društvo mora imati sredstva dostatna za isplatu naknade članu koji istupa, u skladu s načelom održanja kapitala društva. Ako se ova treća pretpostavka nije ispunila, član umjesto istupa može ustati tužbom za prestanak društva. ${ }^{9}$

\subsection{Opravdan razlog za istup}

Pravo člana na istup temelji se na postojanju opravdanog razloga za takvu mjeru. Naš Zakonodavac navodi da opravdani razlog za istupanje člana iz društva postoji naročito ako mu ostali članovi društva ili neki od organa društva prouzroče štetu, ako je spriječen u ostvarenju svojih prava u društvu ${ }^{10}$ ili mu neki organ društva

8 Altmeppen, H., u: Roth, G./Altmeppen, H., ,,Gesetz betreffend die Gesellschaften mit beschränkter Haftung“, 7., Neubearbeitete Auflage, Verlag C.H.Beck, München, 2012, § 60 Rn. 112.

9 Schindler, H., o. c. u bilj. br. 4., § 34, Rn. 170. To će biti moguće samo ako član raspolaže udjelima koji se odnose na najmanje 1/10 temeljnog kapitala društva.

10 Primjerice vidi presudu Visokog trgovačkog suda RH (VTS) od 23. III. 1999., Pž-4019/98, dostupnu na http://www.iusinfo.hr, pregledano 12. IX. 2016. Činjenica da je član spriječen u ostvarenju svojih prava u društvu jedan je od opravdanih razloga. Iz spisa proizlazi da je tužitelj kao osnivač društva R. d.o.o. Osijek podnio tužbu protiv društva kao tuženika, radi istupanja tužitelja iz društva, iz razloga što je izmedu tužitelja i drugog osnivača društva V. J. došlo do narušavanja međusobnih odnosa, a iz razloga jer drugi osnivač nije obavljao svoj dogovoreni dio posla administrativne prirode, te je tužitelj za obavIjanje tih poslova morao uposliti kćer drugog osnivača. U konkretnom predmetu tužitelj je dokazao da je spriječen u ostvarenju svojih prava u društvu jer mu je onemogućen pristup u poslovne prostorije društva s obzirom na to da je drugi osnivač promijenio bravu na poslovnim prostorijama, a što je razvidno $\mathrm{i}$ iz iskaza drugog osnivača - V. J. 
nameće nerazmjerne obveze. Iz riječi „,naročito“ jasno proizlazi da lista pretpostavki koje predstavljaju opravdan razlog za istup člana iz društva tom odredbom nije zaključena, već postojanje takvog razloga treba utvrditi od slučaja do slučaja. Pri tome valja provesti sveobuhvatnu analizu svih pojedinačnih interesa te svih ostalih okolnosti konkretnog slučaja, a ne samo neposrednih interesa odnosno povoda za istup. ${ }^{11} \mathrm{~S}$ motrišta člana koji istupa bitna je njegova volja za napuštanjem društva, okolnost da je član društva te da u društvu ima gospodarski interes koji treba zaštititi. Interes ostalih članova, kao i samog društva, jest održanje imovine te sprečavanje svih mjera kojima se negativno utječe na likvidnost društva. Nije bez značaja niti okolnost da je u konkretnom slučaju riječ o „više osobno“ ustrojenom d.o.o.-u. Naime, ako postoji takva personalna i gospodarska vezanost članova međusobno te članova i društva kakva postoji kod društava osoba, tada bi članu tim prije trebalo dopustiti da istupi iz društva. To, međutim, ipak ne znači da članovi kapitalno ustrojenih društava s ograničenom odgovornošću nemaju pravo na istup, samo će kod ovih prvih u praksi češće i jednostavnije nastati opravdan razlog za istup. ${ }^{12}$

Za ocjenu o tome smije li član istupiti iz društva treba ispitati u kojoj je mjeri član koji istupa svojim ponašanjem doveo do toga da je njegov članski položaj u društvu postao neodrživ. S druge strane, nedopustivo ponašanje ostalih članova ne može biti samostalna pretpostavka za istup. Nerijetko će biti slučaj da su svi članovi svojim ponašanjem dali podjednak doprinos u stvaranju negativnih odnosa u društvu. Clan koji je u većoj mjeri uzrokovao takvo stanje društva ne samo da ne smije istupiti iz društva već će odgovarati društvu za štetu zbog povrede članske dužnosti na lojalno postupanje, a moguće je da su se time ispunile pretpostavke i za njegovo isključenje iz društva.

Pretpostavke koje predstavljaju opravdan razlog za istup mogu se podijeliti u tri grupe slučajeva. U prvu grupu slučajeva spadaju strukturne promjene kojima se znatno mijenjaju odnosi u društvu, u drugu spadaju slučajevi koji se vezuju uz ostale članove društva a u treću slučajevi koji su u svezi s osobom člana koja istupa iz društva.

Opravdan razlog za istup može nastati zbog strukturnih promjena kojima se (znatno) mijenjaju odnosi u društvu. Člana se ne može prisiliti da i dalje bude član društva ako su se od trenutka osnivanja društva znatno promijenile okolnosti, a to će posebice biti slučaj ako se izmijenio pravni temelj udruživanja - društveni ugovor. U tom smislu, opravdan razlog za istup može biti donošenje odluke o povećanju temeljnog kapitala a kojoj odluci se taj član usprotivio ili ako se na skupštini donese odluka o opsežnim ulaganjima u rizični poslovni pothvat što može utjecati na likvidnost društva. Također je riječ o strukturnoj promjeni ako se različitim mjerama utječe na odnos snaga u društvu - primjerice uspostavljanje koncerna, pa se društvom upravlja prema uputama vladajućeg društva u koncernu. Član ima pravo na istup i onda kada su se ispunile pretpostavke za prestanak društva.

11 Altmeppen, H., o. c. u bilj. br. 9., § 60, Rn. 109.

12 Fastrich, L., u: Baumbach/Hueck, „Gesetz betreffend die Gesellschaften mit beschränkter Haftung“, 20. Auflage, Verlag C. H. Beck, München, 2013., § 34 Anh. Rn. 19. 
Načelno, kod izmjena društvenog ugovora, član koji se tome usprotivio nije dužan čekati da zbog tih izmjena prvo nastanu po njega negativni učinci, već može odmah izjaviti da istupa iz društva. Dvojbeno je pripada li pravo na istup članu koji je kod glasovanja o nekom važnom pitanju bio suzdržan. Naime, moglo bi se tumačiti da i takvo očitovanje volje predstavlja oblik neslaganja s odlukom posebice onda ako je riječ o društvu s razmjerno malim brojem članova. Prema široko prihvaćenom polazištu, pravo na istup pripada i članu koji je glasovao za neku odluku (nije joj se usprotivio) jer je kod glasovanja bio vezan dužnošću na lojalno postupanje. To će, primjerice, biti slučaj ako je glasovao za povećanje kapitala društva jer je to važna mjera za sanaciju društva iako je svjestan da on osobno nema dostatna sredstva za preuzimanje novih udjela pa želi istupiti zbog znatnog smanjenja svog udjela u društvu. ${ }^{13}$ Ako je postizanje svrhe društva postalo nemoguće ili ako postoje drugi bitni razlozi za njegov prestanak članstva, a koji se tiču odnosa u društvu, tada je nastao opravdan razlog za istup člana. To posebice vrijedi onda ako član ima udjele koji se odnose na manje od $10 \%$ temeljnog kapitala tog društva jer tada član niti ne može ustati s tužbom za prestankom društva, a istovremeno spomenuto društvo kroz dulji period ne ostvaruje dobit koju bi isplatilo članovima. ${ }^{14}$ Nitko nije dužan svoj kapital (imovinu) vezati uz projekte koji nemaju zdrave gospodarske temelje odnosno ne donose dobit. No, ipak, očekuje se da članovi prethodno poduzmu sve što je u njihovoj moći kako bi društvo prevladalo krizu.

Nadalje, opravdan razlog za istup predstavlja i izmjena svrhe (cilja) društva jer ne može se očekivati od člana da ostane u društvu ako su se znatno izmijenili uvjeti u odnosu na one u kojima je društvo osnovano. ${ }^{15}$ To će biti slučaj ako je došlo do znatnog poslovnog širenja društva i pojačanih ulaganja te je tako znatno porastao poduzetnički rizik kao i onda ako je društvo počelo poslovati u gospodarskoj grani u kojoj inače posluje član pa mu društvo postaje konkurencija. Odnosi u društvu promijenili su se i u slučaju kada je drugi član već istupio ili je isključen iz društva - tada se ispunio opravdan razlog za istup kod preostalih članova društva. ${ }^{16} \mathrm{I}$ kod povećanja temeljnog kapitala pravo na istup može imati član koji se toj odluci suprotstavio ili je za nju glasovao isključivo zbog dužnosti na lojalno postupanje i to samo onda ako postoji opravdana sumnja da bi nastala obveza podmirenja nedostajućih iznosa. Ćlan tada može dati izjavu o istupu i prije nego što je nastala odgovornost odnosno prije nego li se pokazalo da je neka odluka bila štetna za društvo. Za navedene pravne učinke kojima se mijenjaju odnosi u društvu nije potrebno da je tu riječ o formalnoj izmjeni odredaba društvenog ugovora. Dostatno je da je riječ o mjeri koja je faktički na snazi a može se pripisati društvu.

U drugu skupinu opravdanih razloga za istup spadaju svi oblici zlouporabe vladajućeg položaja kao i svi slučajevi kada je važan razlog za istup nastao zbog

13 Fastrich, L., o. c. u bilj. br. 13., § 34 Anh. Rn. 19.

14 Röhricht, V., o. c. u bilj. br. 6., str. 386.

15 To načelo razvijeno je u sudskoj praksi njemačkih sudova u svezi s komanditnim društvom, ali može se primijeniti i na društvo s ograničenom odgovornošću. Ono je i temelj prava člana na istup kod statusnih promjena društva. Detaljnije vidi kod Fastrich, L., o. c. u bilj. br. 13., § 34 Anh. Rn. 20.

16 Röhricht, V., o. c. u bilj. br. 6., str. 379. 
ponašanja ostalih članova koji su većina u društvu. Primjerice, ako skupština većinom glasova opetovano donosi odluke o tome da se dobit ne raspoređuje članovima već se pohranjuje u rezerve kapitala. Poseban oblik zlouporabe vladajućeg položaja jest pretjerano zadržavanje dobiti u društvu kroz dulje razdoblje. Članovi društva većinom glasova mogu odlučiti da se dobit neće rasporediti članovima već će se te iznose rasporediti u rezerve ili u zadržanu dobit. ${ }^{17}$ Tako je manjinskim članovima uskraćeno pravo da temeljem svog ulaganja ostvaruju dobit. To je vidljivo posebice onda kada vladajući član prima izdašnu naknadu za rad u svojstvu direktora pa nije niti zainteresiran za isplatu dobiti. Manjinski članovi tada bi mogli ustati s tužbom temeljem dužnosti člana na lojalno postupanje i zahtijevati da se donese odluka o isplati dobiti. Ako većinski članovi opetovano usvajaju takve odluke, od ostalih članova nije tada opravdano očekivati da svaki put ustaju s tužbom nego im se mora dopustiti istup iz društva. ${ }^{18}$ Otvoreno je pitanje treba li članu dopustiti istup i onda kada zadržavanje dobiti ne predstavlja zloporabu prava? S jedne strane, ne smije se manjinskim članovima dati pravo da istupom ucjenjuju vladajućeg člana. S druge strane, riječ je o razlogu za istup iz sfere člana pa bi pod određenim pretpostavkama trebalo dopustiti da istupi, primjerice u slučaju velikog poslovnog širenja društva kada se članu može dati pravo na istup jer više nije u stanju " pratiti" poslovni pothvat. ${ }^{19} \mathrm{Tu}$ spadaju i druge mjere kojima je zajedničko da su poduzete u skladu sa zakonom, ali su suprotne načelu savjesnosti i poštenja odnosno predstavljaju zlouporabu prava. Dosljednom primjenom načela o supsidijarnoj primjeni pravnog sredstva istupa iz društva mogli bismo zaključiti da je član uvijek dužan koristiti blaže pravno sredstvo, a u ovim je slučajevima to sredstvo tužba za pobijanje odluka skupštine. Međutim, nije od člana opravdano očekivati da ostane u društvu ako

17 U presudi Visokog trgovačkog suda RH navodi se da je opravdani razlog za istupanje člana iz društva, između ostalog, prouzročenje štete članu društva. Uprava društva čini štetu članu društva ako neosnovano odbija dati suglasnost na zahtjev člana odštetu za prijenos poslovnog udjela uz (postupanjem u ime društva) istodobno stjecanje vlastitih poslovnih udjela od drugih članova društva i to smanjenjem temeljenog kapitala i rezervi koje ne smije upotrijebiti za isplatu članovima društva. Tužitelj raspolaže s više poslovnih udjela što iznosi $12,635 \%$ od vrijednosti temeljnog kapitala društva te da svoju tužbu za istupanjem iz društva tuženika tužitelj temelji na odredbi članka 420. stavak 2. Zakona o trgovačkim društvima, smatrajući da za istupanje iz društva tuženika postoje „opravdani razlozi i naročito opravdani razlozi", a oni se očituju u tome da je tužitelj stupio u članstvo društva u sasvim drugim uvjetima nego što su sada s obzirom na izvršene izmjene akata društva, da je tužitelj sustavno ograničavan u vođenju poslovne politike nadglasavanjem, da je dobio otkaz ugovora o radu i da je razriješen funkcije člana uprave tuženika, da je stavljen u neravnopravan položaj u odnosu na druge članove društva kojima je tuženik dozvolio istupanje iz društva premda su nakon tužitelja podnijeli zahtjev, a raspolagali su s približno istom veličinom poslovnih udjela kao i tužitelj, kao i to da su nakon donesene tuženikove odluke o tužiteljevu isključenju ,tužitelju sustavno uskraćena sva prava kao člana društva na koja je do tada imao pravo do istupa sve do donošenja pravomoćne odluke suda o istupu iz društva i isplati visine naknade tržišne vrijednosti njegovog udjela te da ,tužitelju nakon isključenja više nije bilo dopušteno prisustvovati sjednicama Skupštine“". Također, iz spisa proizlazi da se tužitelj obratio upravi tuženika za davanje suglasnosti za prijenos poslovnog udjela kao i to da uprava tuženika nije pozitivno odgovorila na tu tužiteljevu zamolbu niti je stavila na dnevni red tuženikove Skupštine davanje suglasnosti na tužiteljev prijenos poslovnog udjela. Vidi presudu VTS-a od 1. VII. 2008., Pž-7151/05, dostupnu na http://www. iusinfo.hr, pregledano 12. IX. 2016.

18 Fastrich, L., o. c. u bilj. br. 13., § 29 Rn. 29. i dalje.

19 Röhricht, V., o.c. u bilj. br. 6., str. 383. 
neprestano treba ustajati s tužbama za pobijanje odluka skupštine pa i tada ima pravo istupiti iz društva. ${ }^{20}$

Dvojbeno je ima li manjinski član pravo na istup ako vladajući član ima prevladavajući utjecaj ili se društvo poveže u koncern. U literaturi o tome postoji nekoliko različitih mišljenja. Prema prvom, članu pripada pravo na istup u slučaju nastanka faktičnog koncerna. Prema drugom, pravo na istup postoji samo kad nastane tzv. kvalificirani faktični koncern. Prema trećem mišljenju, za istup je dostatno da postoji jednostavan odnos ovisnosti, a to znači da na jedno (ovisno) društvo drugo društvo (vladajuće društvo) može imati neposredno ili posredno prevladavajući utjecaj. ${ }^{21}$

Ovisnost društva o članu ne mora se nužno temeljiti na većinskom udjelu već može proizlaziti i iz posebnih prava člana. Ako su ta prava uređena društvenim ugovorom, tada se ostali članovi ne mogu pozivati na njih i tražiti istup iz društva. Nemaju to pravo niti onda ako se naknadno mijenjao društveni ugovor jer su oni to morali usvojiti, a njihovo odobrenje bilo je nužno jer se tim izmjenama smanjuju njihova prava. Tko se složio, nema pravo na istup osim ako odluku nije usvojio zbog dužnosti na lojalno ponašanje ili ako se posebno pravo ostvaruje na nedopušten način. Nadalje, ako je sklapanjem poduzetničkog ugovora nastao koncern, nije potrebno raspravljati o pravu člana na istup zbog važnog razloga jer on ima na raspolaganju druga dva sredstva. Prvo, ako se odluka o sklapanju poduzetničkog ugovora donosi jednoglasno, član to može spriječiti. Drugo, ako se ta odluka donosi kvalificiranom većinom pa član bude nadglasan, ostaje mu pravo da izjavi istup i zatraži isplatu otpremnine (čl. 492. ZTD-a).

Opravdan razlog člana za istup može nastati i zbog ponašanja ostalih članova društva. Ako se jedan od članova ponaša tako da se ispunila pretpostavka za njegovo isključenje, umjesto da se vodi postupak isključenja, drugi član može istupiti iz društva. Od njega nije opravdano očekivati da troši vrijeme na provođenje postupka isključenja te da mora dalje nastaviti s društvom bez isključenog člana. Nadalje, svako trajno nezakonito postupanje ostalih članova daje preostalom članu pravo na istup. Članu pripada pravo na istup ako su vladajući članovi počinili grubu povredu interesa društva zloporabom svojeg vladajućeg položaja. Iz toga proizlazi zaključak da je važna funkcija instituta istupa upravo zaštita manjinskih članova. To

20 Ibid., str. 381. i dalje.

21 Vidi čl. 475. ZTD-a. Pretpostavlja se da je društvo koje se nalazi u većinskome sudjelovanju ovisno o društvu koje u njemu ima većinski udio. Smatra se da neko društvo može imati prevladavajući utjecaj u drugome društvu ako kao dioničar ili član društva ima pravo izabrati odnosno imenovati i opozvati imenovanje odnosno razriješiti većinu članova uprave, odnosno većinu izvršnih direktora ili članova nadzornog odbora odnosno upravnog odbora društva ili na temelju sporazuma sklopljenog s drugim dioničarima ili članovima tog društva ima kontrolu nad većinom glasačkih prava u društvu.

Kod d.o.o.-a zbog posebnog položaja skupštine (nema nadzornog odbora), član koji ima većinski udio praktički vlada tim društvom, a ne primjenjuju se odredbe iz Zakona o preuzimanju d.d.-a kojima se posebno uređuju dužnosti dioničara koji je stekao kontrolni paket dionica. On mora manjinskim dioničarima isplatiti otpremninu za istup iz društva. Iako je položaj manjinskih članova d.o.o.-a povoljniji nego položaj manjinskih dioničara, ipak se može zaključiti da član ima pravo na istup u slučaju ovisnosti njegovog d.o.o.-a o vladajućem društvu. Otpremninu članu isplaćuje njegovo društvo, a ne vladajuće društvo. Kallmeyer, H., ,Schutz vor Übernahmen in der GmbH““, GmbHR, br. 14 (2001.), str. 745. 
je svojevrsni sigurnosni mehanizam koji se aktivira ako u konkretnom slučaju od člana nije opravdano očekivati da se koristi tužbom na pobijanje odluka skupštine društva ili tužbom u ime društva zbog nezakonitog ponašanja vladajućeg člana. Ako vladajući član jasno stavi manjinskom članu na znanje da ne namjerava voditi računa o njegovim interesima, tada manjinski član može istupiti iz društva bez obzira na to je li ispunjena pretpostavka o objektivnom odnosu ovisnosti. ${ }^{22}$

Svaka mjera, ponašanje člana kojim se suprotno načelu savjesnosti nanosi šteta ili se diskriminira drugog člana može predstavljati opravdan razlog za istup. Isto vrijedi za slučaj sukoba (grubog neslaganja) članova zbog čega nije opravdano očekivati da nastave suradnju. Čak i onda kada su se ispunile pretpostavke za isključenje člana ili prestanak društva, drugi član ima pravo na istup. Ipak, ne daje svako neslaganje (sukob) članova pravo na istup. Tako, primjerice, član nema pravo na istup ako uprava sa zakašnjenjem preda godišnja financijska izvješća ili počini pogrešku u svezi sa sklapanjem nekog ugovora. Važan razlog za istup nije nastao niti ako se između člana i društva vodi sudski spor iz radnog odnosa (ako je član ujedno i zaposlenik društva). Nije nastupio opravdan razlog za istup niti kada društvo članu ne dopusti prijenos udjela, osim ako je negativna odluka donesena suprotno načelu savjesnosti i poštenja jer nije postojao razlog da se odbije taj zahtjev člana. ${ }^{23}$

Važan razlog za istup može nastati i u svezi s članom koji istupa (osobni razlozi). U svezi s pitanjem opravdanosti, utemeljenosti prava na istup, ključno je pitanje u čijoj domeni je nastao opravdani razlog: u svezi s društvom tj. ostalim članovima ili u svezi s članom koji istupa iz društva. U domeni člana koji istupa mogu postojati privatni razlozi koji nisu od značaja, ali i takvi razlozi koji objektivno imaju veze s članstvom u društvu pa stoga mogu, u kombinaciji s drugim okolnostima, predstavljati opravdan razlog za istup. ${ }^{24}$ Clanu načelno pripada pravo na istup ako mu obveza na ispunjenje dodatnih činidaba zbog promijenjenih okolnosti postane neopravdano otežana. ${ }^{25} \mathrm{~S}$ obzirom na to da se član ne smije jednostranom izjavom volje osloboditi dužnosti na ispunjenje dodatne činidbe, preostaje mu samo da izjavi istup iz društva. Promjena prebivališta člana kod personalno ustrojenog d.o.o.-a može predstavljati opravdan razlog za njegov istup ako je zbog preseljenja postalo znatno otežano ostvarenje njegovih članskih prava i ispunjenje članskih dužnosti. Isto vrijedi i za slučaj dugotrajne teže bolesti člana. Nadalje, razvod braka supružnika koji su jedini članovi društva može predstavljati opravdan razlog za istup jednog od njih iz društva. ${ }^{26}$ Opravdan razlog može se sastojati u tome da član više ne može financijski pratiti širenje društva i ulaganje u nove poslovne pothvate. ${ }^{27}$ Dvojbeno je predstavlja li opravdan razlog okolnost da član hitno mora podmiriti privatne

22 Röhricht, V., o. c. u bilj. br. 6., str. 382.

23 Lutter, M., o. c. u bilj. br. 5., § 34 Anh. Rn. 72.

24 Seibt, C., u: Scholz, GmbHG: Kommentar zum GmbH-Gesetz, 11. Auflage, Verlag Otto Schmidt, Köln, 2012, § 34 Anh. Rn. 12.

25 Fastrich, L., o. c. u bilj. br. 13., § 3 Rn. 51.

26 Seibt, C., o.c. u bilj. br. 25., § 34 Anh. Rn. 13

27 Schindler, H., Das Austrittsrecht in Kapitalgesellschaften, C. H. Beck, München, 1999., str. 60. 
obveze. Načelno, moglo bi se zaključiti da osobni razlozi člana ne predstavljaju opravdan razlog za istup, ali bi se ta pretpostavka mogla ispuniti ako su se uz osobne razloge ispunile i druge pretpostavke. No, s druge strane, nema razloga da se članu istup onemogući ako njegovim istupom društvo i preostali članovi ne dolaze u lošiji položaj, odnosno ne nastaje im šteta. Okolnost da član ne može uplatiti ulog u cijelosti ili ne može izvršiti dodatne uplate u novcu, nije dostatna za istup. Naime, član se može osloboditi obveze tako da svoj poslovni udio stavi na raspolaganje radi podmirenja obveze, a za slučaj da je obveza na dodatnu uplatu ograničena na određeni iznos, primjenjuju se odredbe za slučaj kada član nije uplatio svoj ulog (čl. 398. - 403. ZTD-a). Spomenuta sredstva imaju prednost pred pravom člana na istup. ${ }^{28}$ Ako se društvo složi sa zahtjevom člana za istup iz društva, tada ne mora postojati opravdani razlog. ${ }^{29}$

Kada postoje opravdani razlozi za istupanje, član društva može ustati s konstitutivnom tužbom i zahtijevati da sud donese presudu o njegovom istupanju iz društva, neovisno o tome što je predviđeno društvenim ugovorom (čl. 420. st. 2. reč. 1.ZTD-a). Tužba se podnosi nadležnom trgovačkom sudu na čijem se području nalazi sjedište društva upisano u sudskom registru, bez obzira na mjesto prebivališta člana društva (čl. 40. st. 1. ZTD-a). Riječ je o prisilnoj normi, zbog čega se član društva ne može unaprijed odreći prava na tužbu za istupanje (čl. 420. st. 4. ZTD-a).

U postupku pokrenutom tužbom, član društva mora dokazati postojanje nekog od navedenih opravdanih razloga kao i da su za njihovo nastajanje odgovorni ostali članovi društva ili neki od organa društva, a time i samo društvo. Istodobno, član društva koji želi iz njega istupiti, mora postaviti zahtjev za isplatu naknade za njegov poslovni udjel koji stavlja na raspolaganje društvu. Taj zahtjev mora sadržavati iznos naknade za poslovni udio i primjeren rok u kojem će mu se ta naknada isplatiti (čl. 420. st. 2. reč. 3. ZTD-a).

Utvrdi li sud da postoje razlozi koji opravdavaju nakanu člana društva kao tužitelja da iz njega istupi, usvojit će tužbeni zahtjev za istupanje člana iz društva, te istodobno odrediti rok društvu za isplatu naknade tržišne vrijednosti poslovnog udjela člana koji po toj presudi istupa iz društva. Rok za isplatu naknade sud određuje prema poslovnim potrebama i stanju društva (čl. 420. st. 2. reč. 4. i 5. ZTD-a). ${ }^{30}$

28 Emmerich, V., u: Scholz, GmbHG: Kommentar zum GmbH-Gesetz, 11. Auflage, Verlag Otto Schmidt, Köln, 2012., § 2 Rn. 85.

29 Vidi presudu OLG Köln od 21. -V. 1996. - 3 U 130/95, dostupnu na https://openjur.de/u/445206. html, pregledano 12. IX. 2016. Usp. Barbić, J., Pravo društava - društva kapitala, Sv. II., 5. izdanje, Organizator, Zagreb, 2010., str. 166., koji ističe da važan razlog za istup mora postojati kada se pravo na istup ostvaruje tužbom jednako kao i kad je pravo na istup detaljnije uređeno društvenim ugovorom. Za pretpostaviti je da Autor također smatra da član može istupiti i bez navođenja važnog razloga ako se s tim složi skupština te ako isplata naknade nije suprotna odredbama o održanju kapitala.

30 Tako Ćesić, Z. u: Gorenc, V., Komentar Zakona o trgovačkim društvima, IV. izdanje, RRiF, Zagreb, 2008., str. 996- 997. Suglasan i Barbić, J., o. c. u bilj. br. 29, str. 169. Drugačije Slakoper koji ističe da prema tekstu odredbe član društva tužbom može ,zahtijevati istupanje”, iz čega bi se moglo zaključiti kako sud presudom „odobrava istupanje”. Ima li takva presuda utvrđujući (deklaratorni) ili pravostvarajući (konstitutivni) značaj? Odgovoru na ovo pitanje pomaže odredba prema kojoj „članstvo u društvu člana koji je istupio iz društva... prestaje kada... se isplati naknada" tržišne vrijednosti njegova udjela ili vrate uložene stvari, a ta isplata će neminovno uslijediti poslije presude, jer kad bi prethodila presudi, onda bi 


\section{2. Supsidijarnost}

Istup zbog važnog razloga bit će dopušten samo onda kada ne postoji blaže pravno sredstvo koje bi član mogao koristiti u konkretnom slučaju. Stoga član koji namjerava istupiti iz društva prvo mora pokušati provesti pravni posao kupoprodaje poslovnog udjela, a pri tome je dužan prihvatiti i razuman gubitak - pad vrijednosti svog poslovnog udjela. Naime, pravo člana na istup nikako ne smije postati sredstvo kojim će član rizik pada vrijednosti poslovnog udjela prebaciti na društvo i ostale članove. Okolnost da su poslovni udjeli načelno prenosivi kod istupa predstavlja dodatan teret za člana. Čak i kada je riječ o vinkuliranim poslovnim udjelima za koje društvo nije dopustilo prijenos, nije time nastao opravdan razlog za istup. Načelno, ako društvo odbije prijenos, član treba naći drugog kupca, osim ako je jasno da mu društvo neće dopustiti prijenos. ${ }^{31}$ Može se zaključiti da član najčešće neće moći uspješno raspolagati svojim poslovnim udjelom ako se uz taj udjel vezuju i dodatne obveze ili ako se u tom trenutku za poslovni udio ne može dobiti niti približno cijena koja odgovara realnoj vrijednosti poslovnog udjela. Ne smije se zaboraviti da ne postoji uređeno tržište na kojem bi se obavljala kupoprodaja poslovnih udjela. Tu treba vagati sve okolnosti i utvrditi do koje mjere (iznosa) član mora prihvatiti financijski gubitak kod prodaje poslovnog udjela.

Član će prije ostvariti pravo na istup u slučajevima kada je drugi član društva zlouporabio svoj položaj nego onda kada član istupa zbog osobnih razloga, a taj kriterij valja primijeniti i kod određivanja iznosa naknade koja pripada članu. Ako je važan razlog nastao u sferi člana koji istupa - što se može dogoditi i ako društvo na zakonit način zadržava dobit, ali je takvo stanje za člana neodrživo, on bi, jednako kao u slučaju kada važan razlog za istup nastane zbog društva ili ostalih članova, trebao poduzeti pojačane napore da proda svoj poslovni udio kako bi izbjegao i veći gubitak. ${ }^{32}$ Nije nezamisliv niti slučaj da član koji namjerava istupiti naloži društvu da mu pronađe kupca za poslovne udjele pa će se tako izbjeći dužnost društva na isplatu naknade članu koji istupa. Ako zbog nepažnje ostalih članova kupac odustane od kupoprodaje poslovnog udjela, ta im okolnost sigurno ne ide u korist pa bi tada članu trebalo dopustiti istup iz društva.

\footnotetext{
iz toga proizlazila suglasnost društva s istupanjem člana pa bi i samo podnošenje tužbe radi istupanja u tom trenutku postalo nepotrebno. Iz toga ujedno proizlazi kako članstvo u društvu ne prestaje u trenutku pravomoćnosti presude o istupanju, a to znači da presuda suda o istupanju ne bi mogla imati konstitutivni (pravostvarajući) značaj jer u trenutku njene pravomoćnosti ne nastaje novo pravno stanje (član ne istupa) nego novo pravno stanje (istupanje) nastaje tek kad se istupajućem članu isplati naknada odnosno vrate uložene stvari. Pravo člana na istupanje podrazumijeva, dakle, i njegovo pravo zahtijevanja od društva ili povrat uloženog u društvo ili isplatu tržišne vrijednosti svoga poslovnog udjela, što se može ocijeniti sukladnim okolnosti što on istupa iz društva zbog nelojalnog postupanja društva prema njemu. I to svoje pravo - makar je njegova pretpostavka prethodno utvrđenje opravdanosti istupanja - član društva mogao bi ostvarivati tužbom sudu upravljenom ili na isplatu tržišne vrijednosti udjela ili na povrat uloženih stvari odnosno prava. Slakoper, Z., „Društvo s ograničenom odgovornošću“, Računovodstvo i financije, Zagreb, 2001., str. 306-307.

31 Seibt, C., o. c. u bilj. br. 25., § 34 Anh. Rn. 9.

32 Altmeppen, H., o. c. u bilj. br. 9., § 60, Rn. 111.
} 
Nadalje, član može tužbom pobijati odluke skupštine ili osporavati mjere koje predstavljaju zloporabu, tražiti opoziv direktora koji nije postupao kao uredan i savjestan gospodarstvenik te se i inače koristiti pravima koja mu stoje na raspolaganju kao članu društva. Međutim, ako član mora često koristiti ta pravna sredstva, treba mu dopustiti istup jer nije opravdano očekivati da se svaki put mora koristiti tim tužbama. ${ }^{33}$

Član može istupiti iz društva čak i onda kada mu pripada pravo da tužbom zatraži prestanak društva jer je u tom slučaju istup blaže pravno sredstvo od spomenute tužbe. ${ }^{34}$ Također, ako je društvenim ugovorom uređeno pravo člana da izjavi otkaz društvenog ugovora, a koja izjava proizvodi učinke s posljednjim danom poslovne godine (odredba koja inače vrijedi za društva osoba), član bez obzira na tu odredbu može zatražiti istup ako prema okolnostima slučaja nema valjanog razloga da ostane u društvu i čeka nastupanje roka za otkaz društvenog ugovora. ${ }^{35}$

Kao i za slučaj isključenja člana, kod istupa mora se ispuniti i negativna pretpostavka - isplata naknade članu ne smije biti suprotna odredbama o održanju kapitala. Osnovna pretpostavka za to jest da je član koji istupa u cijelosti unio svoj ulog u društvo. Umjesto toga, član može predložiti smanjenje temeljnog kapitala društva. Ako je radnja isplate naknade suprotna odredbama o održanju kapitala, tada se ne može provesti postupak istupa a članu preostaje mogućnost da ustane s tužbom za prestanak društva. ${ }^{36}$

Pitanje istupa člana može se pobliže urediti društvenim ugovorom no njime se ne može isključiti pravo članova na istup zbog važnog razloga jer je riječ o neotuđivom članskom pravu. ${ }^{37} \mathrm{~S}$ druge strane, u društvenom ugovoru moguće je

33 Eschenlohr, H., „Beschränkungen der Austritts- und Kündigungsmöglichkeiten des Gesellschafters einer Familien-GmbH“", Festschrift fur Walter Sigle, OVS Verlag, Köln, 2000., str. 139.

34 Usp. Barbić, J., o. c. u bilj. br. 29, str. 169.

35 Fastrich, L., o. c. u bilj. br. 13., § 34 Anh. Rn. 22.

$36 \mathrm{Uz}$ pretpostavku da na njegov poslovni udjel otpada najmanje deseti dio temeljnog kapitala društva. Vidi čl. 468. st. 2. ZTD-a.

37 Neovisno o odredbama društvenog ugovora, član društva može konstitutivnom tužbom kod suda zahtijevati istupanje iz društva ako za to postoje opravdani razlozi. Član društva može pod određenim pretpostavkama istupiti iz društva ili tužbom tražiti da sud odredi prestanak članstva. Član društva nije, doduše, ovlašten, kada god to zaželi, istupiti iz društva. Za istupanje člana moraju postojati važni razlozi. Istupanje može biti uređeno društvenim ugovorom, ali u tom slučaju u ugovoru moraju biti uređeni uvjeti pod kojima član može istupiti iz društva, postupak u kojemu se istupanje provodi i posljedice istupanja u odnosu na društvo i na članove. Ne radi se o prestanku članstva prestankom poslovnog udjela, niti prepuštanju udjela trećima (članovima društva ili osobama izvan društva) nego član svoj udjel pod određenim pretpostavkama stavlja na raspolaganje društvu. Radi se o pravnom sredstvu kojim se član može poslužiti samo kada druga sredstva ne mogu dati rezultate. Ako društvenim ugovorom nije određeno što se smatra važnim razlogom za istupanje, može se raditi u načelu o razlozima u samom članu koji istupa, odnosima u društvu ili odnosima s drugim članovima društva. Poglavito se može, kada se radi o istupanju zbog ponašanja drugih članova, dopustiti istupanje zbog nelojalnosti drugog člana ili članova, izvlačenju sredstava iz društva, onemogućavanju članu da se koristi svojim članskim pravima i sl. Ako društvenim ugovorom i nije posebno propisano da član može istupiti, to se pravo može ostvariti konstitutivnom tužbom. Član koji ishodi pravo na istupanje ima pravo na naknadu za poslovni udio. Vrijednost poslovnog udjela određuje se prema vrijednosti u vrijeme istupanja, neovisno o nominalnoj vrijednosti udjela. Vidi presudu Visokog trgovačkog suda RH (VTS) od 3. VI. 2003., Pž-2467/01, dostupnu na www.iusinfo.hr, pregledano 12. IX. 2016. 
navesti konkretne pretpostavke koje predstavljaju opravdan razlog za istup. Moguća je i negativna enumeracija - navođenjem slučajeva kada član nema pravo na istup. Društvenim ugovorom može se utvrditi i maksimalni iznos naknade koja pripada članu koji istupa, ali to ne smije imati za posljedicu onemogućenje istupa člana iz društva zbog niskog iznosa naknade. Takva bi odredba bila bez učinka jer se njome neizravno ograničava pravo na istup. ${ }^{38}$

S druge strane, društvenim ugovorom može se olakšati pravo na istup. Tako se, primjerice, može predvidjeti i redovito pravo na istup, a pri tom mislimo na pravo člana da istupi bez navođenja opravdanog razloga. To će se najčešće urediti tako da se u društveni ugovor unese odredba o otkazu društvenog ugovora kojom se uređuje pravo na istup kod društava osoba, prema kojoj svaki član društva može otkazati društveni ugovor samo s posljednjim danom poslovne godine uz otkazni rok od najmanje šest mjeseci koji mora isteći do toga dana. ${ }^{39}$ To ,redovito“ pravo na istup ne može biti neograničeno pa je najbolje rješenje da se kombiniraju pretpostavke za redoviti istup s važnim razlozima koji opravdavaju istup u svim ostalim slučajevima. Također, treba precizno propisati predstavlja li redovito pravo na istup zapravo pravno sredstvo koje za posljedicu ima prestanak društva ili doista član istupa iz društva koje nastavlja poslovati s ostalim članovima. U slučaju dvojbe, vrijedi pretpostavka da je tu riječ o istupu, a ne o prestanku društva. Taj zaključak proizlazi iz supsidijarne naravi odredaba o prestanku društva u odnosu na odredbe koje uređuju istup člana. ${ }^{40}$

38 Seibt, C., o. c. u bilj. br. 25., § 34 Anh. Rn. 24

39 Vjerovnici člana društva i stečajni upravitelj imaju pravo raspolagati udjelom člana kada je taj udjel predmet ovrhe. Pri tome oni ne podliježu ograničenju raspolaganja ako je inače bilo riječi o vinkuliranim poslovnim udjelima. Ipak, mala je vjerojatnost da će se vjerovnici tim postupkom namiriti. S jedne strane, ne postoji tržište za promet poslovnim udjelima, a s druge strane, u konkretnom slučaju poslovni udio može biti praktički neotuđiv zbog posebnih odnosa unutar društva. Načelno, ako se članu može dopustiti istup jer zbog nedostatka sredstava ne može pratiti pothvat pa bi prema pravilima za društva osoba mogao otkazati ugovor i istupiti iz društva, nema prepreke da se to pravo ne dodijeli njegovim vjerovnicima i stečajnom upravitelju. Samo društvo takvim mjerama nije pogođeno ništa više nego istupom člana. Niti propisi koji uređuju d.o.o. niti temeljna načela tog društva ne govore protiv toga da se to dopusti i vjerovnicima člana d.o.o.-a. Kao i ranije, opet treba pažljivo izvagati sve okolnosti i interese društva i ostalih članova. Ovrha je okolnost iz privatne sfere člana pa bi mjera isključenja člana i plaćanje naknade bila opravdana s polazišta društva. Röhricht, V., o. c. u bilj. br. 6., str. 369.

40 Tako Seibt, C., o. c. u bilj. br. 25., § 34 Anh. Rn. 24. Suprotno mišljenje Schindler, H., o. c. u bilj. br. 4., § 34, Rn. 182. Autor navodi da se u slučaju dvojbe ima smatrati da je pokrenut postupak za prestanak društva. Stoga ostali članovi bez odgode moraju izjaviti da nastavljaju s društvom te moraju preuzeti poslovni udjel člana koji istupa, a iznos naknade utvrđuje se prema iznosu koji bi pripadao tom članu da se proveo postupak likvidacije društva. 


\section{POSTUPAK ISTUPA}

Postupak istupa provodi se u dvije faze: član daje izjavu o istupu i stavlja društvu na raspolaganje svoj poslovni udjel, a potom društvo, uz suradnju člana koji istupa, mora provesti ostale radnje. Do istupanja dolazi tek kada član zajedno s dobivenom naknadom za svoj poslovni udio: a) taj udio ustupi društvu ili b) nekom članu društva ili kome trećemu ili c) pristane na to da ga društvo povuče. ${ }^{41}$

Prva pretpostavka za istup jest odgovarajuće očitovanje volje člana koji istupa iz društva. Riječ je o jednostranoj izjavi volje usmjerenoj ka prestanku članstva i tu izjavu društvo mora zaprimiti. Dostatno je da očitovanje zaprimi jedan od članova uprave. Za valjanost izjave o istupu ne traži se da bude u posebnoj formi, ali se ipak preporučuje da bude u pisanoj formi radi lakšeg dokazivanja. Izjava mora biti bezuvjetna, a u pravilu bit će i neopoziva, no ipak će se moći opozvati temeljem općih pravila o neskladu volje i očitovanja, primjerice zbog zablude. ${ }^{42}$ Treće osobe koje su, primjerice, nositelji založnog prava na poslovnom udjelu ne mogu spriječiti istup člana jer je tu riječ o posebnom neotuđivom članskom pravu. Ako što drugo nije predviđeno društvenim ugovorom, osoba nije prestala biti članom društva trenutkom kada je društvo zaprimilo njegovo očitovanje volje. Od tada član stječe pravo zahtijevati isplatu naknade, a društvo, uz suradnju člana koji istupa, mora u razumnom roku poduzeti neku od mjera raspolaganja njegovim poslovnim udjelom. U tom smislu, društvo može slobodno odlučiti o tome kako postupiti s poslovnim udjelom člana koji istupa iz društva: može ga povući, prenijeti na ostale članove ili na treće osobe pri čemu prethodno može provesti i podjelu udjela, a poslovni udjel može i pridržati prema pravilu o stjecanju vlastitih poslovnih udjela. ${ }^{43}$

\subsection{Pravni učinci izjave o istupu}

Kada društvo zaprimi izjavu o istupu, počinju teći rokovi za isplatu naknade članu te za raspolaganje poslovnim udjelom, ali u pravilu član zadržava svoja članska prava sve dok je imatelj poslovnog udjela u društvu. Privremeno nastavljanje s članom koji istupa za društvo je manje problematično u odnosu na slučaj isključenja člana kada je u interesu društva da takva osoba što prije izgubi članski status. S druge strane, član ima interes zadržati članski status dok se ne razriješi pitanje iznosa naknade. Stoga on ima pravo reagirati na sve mjere kojima se umanjuje imovina društva, a

41 Barbić, J., o. c. u bilj. br. 29, str. 169.

42 Tako Wellhöfer, W., „Ausscheiden eines GmbH-Gesellschafters in der Gesellschaftspraxis“, GmbHR, br. 4 (1994.), str. 217. Izjava o istupu neće proizvoditi učinke ako tako bez odgode zajednički odluče član koji istupa s jedne strane te ostali članovi s druge strane i to odmah nakon što društvo zaprimi spomenutu izjavu. Takvo rješenje je moguće i ako se o tome dogovori član koji istupa s upravom društva $\mathrm{i}$ to samo ako postupak istupa još nije proveden. Uz spomenute sporazume nerijetko se odmah pristupa izmjeni društvenog ugovora čime se poboljšava pravni položaj člana koji je namjeravao istupiti. Detaljnije o tome kod Fastrich, L., o. c. u bilj. br. 13., § 34 Anh. Rn. 24.

43 Vidi presudu OLG Celle od 28. VIII. 2002. - Az. 22 U 159/01 (6. ZS), 22 U 159/01, dostupnu na https://openjur.de/u/313761.html, pregledano 12. IX. 2016. 
time se ugrožava sposobnost društva na isplatu naknade članu. Zbog navedenoga, vrijedi pretpostavka da članska prava ne miruju. Nije pri tom od značaja je li taj član i dalje spreman na suradnju s ostalim članovima. Obveza je društva da, nakon što zaprimi izjavu o istupu, što prije okonča to "pendentno" stanje tako što će članu isplatiti naknadu te poduzeti raspolaganje njegovim poslovnim udjelom. S druge strane, u razdoblju prije isplate naknade, član koji istupa iz društva treba se i dalje ponašati lojalno prema društvu te ne smije zlouporabiti svoja članska prava. On ne smije bez opravdanog razloga glasovati protiv usvajanja odluka koje su na dnevnom redu skupštine, osim onih kojima se utječe na sposobnost društva da mu isplati naknadu. ${ }^{44}$ Ipak, ne smije se zaboraviti da se na stanje imovine društva može utjecati na različite načine, a nerijetko i neizravnim mjerama pa je upitno ima li i neka naoko nevezana odluka učinke na imovinu društva.

Dvojbeno je ima li član pravo sudjelovanja u isplati dobiti nakon što društvo zaprimi izjavu o istupu. Iako postoji mišljenje da bi imao to pravo, načelno je polazište da član koji je poslao izjavu o istupu ima pravo na naknadu zaključno s danom kada je društvo zaprimilo tu izjavu. Ako je član ostvario pravo na dobit, to sve mora biti uključeno u iznos naknade. Međutim, s druge strane, zahtjev za naknadom ne dospijeva u trenutku primitka izjave o istupu pa ne vrijedi ni zaključak da od tog trenutka teku kamate na taj iznos. Iz toga proizlazi da osoba koja je još uvijek član nema pravo sudjelovanja u dobiti koje društvo ostvari nakon što je zaprimilo njegovu izjavu o istupu. Takvo rješenje nije u skladu s načelom savjesnosti i poštenja. Stoga član koji istupa ima pravo sudjelovati u dobiti dok god nije prestao biti članom. Zahtjevom za isplatu dobiti mora se konačno riješiti i pitanje kamata. ${ }^{45}$

Član do okončanja postupka ima sva članska prava, ali i obveze. Tako on i dalje odgovara za podmirenje iznosa koji je jedan od članova trebao uplatiti pa to nije učinio. Tada iznos koji nedostaje moraju podmiriti ostali članovi razmjerno svojim poslovnim udjelima. Nadalje, članovi društva odgovaraju i za naknadu iznosa zbog zabranjenih primanja (isplata). Primarno odgovara član koji je primio zabranjenu isplatu, a ako on ne može vratiti taj iznos, ostali članovi odgovaraju razmjerno visini svojih poslovnih udjela. ${ }^{46}$ Nadalje, ako se vodi postupak istupa, ali se postupak još ne može okončati jer postoji spor između člana i društva o tržišnoj vrijednosti tog poslovnog udjela odnosno nesuglasje o visini naknade koja će se isplatiti članu, tada bi mogla prestati vrijediti odredba o zabrani konkurencije (ako je postojala). Također, ako se zabrana konkurencije proteže i na određeno razdoblje po istupu iz

44 Vidi presudu Njemačkog saveznog suda (BGH) od 30. XI. 2009. - II ZR 208/08, dostupnu na https://openjur.de/u/70895.html, pregledano 12. IX. 2016.

45 Altmeppen, H., o.c. u bilj. br. 9., § 60, Rn. 117.

46 Prema mišljenju nekih autora, drugačije vrijedi ako član istupa zbog neopravdano otegotnih dodatnih obveza (ako su dodatne obveze postale neopravdano otegotne za tog člana). Tada bi se moglo, uzevši u obzir sve okolnosti slučaja, osloboditi tog člana dužnosti ispunjenja dodatnih obveza do okončanja postupka, a njegova članska prava u međuvremenu miruju. Takvo rješenje zastupljeno je u starijoj literaturi i sudskoj praksi, a djelomično i danas. Ističe se da postoji sukob interesa kod člana koji je izjavio istup, ali je zadržao sva članska prava. No ipak protiv takvog zaključka ukazuje okolnost da su članska prava jedinstvena, a mirovanjem prava glasa izmijenio bi se odnos snaga u društvu. No nema prepreka da se takav pravni učinak istupa uredi društvenim ugovorom. Ibid., Rn. 114. 
društva, tada taj rok počinje teći nakon primitka izjave o istupu, a ne tek od trenutka kada je član brisan iz popisa članova.

Povlačenjem udjela društvo eliminira člana. Povlačenje udjela moglo bi proizvoditi pravne učinke prije plaćanja naknade. Ali, ako poslovni udjel nije u potpunosti uplaćen ili društvo nema imovinu dostatnu za isplatu naknade u trenutku istupa, ne može se uspješno okončati postupak istupa člana. Ne pronađe li se kupac, stjecatelj njegovih poslovnih udjela (drugi član društva ili treće osobe), preostaje mu samo da ustane s tužbom za prestanak društva.

Pravni učinci istupa mogu se posebno urediti i društvenim ugovorom. Tako se može urediti da je trenutkom primitka izjave o istupu ta osoba prestala biti članom društva, da njezina prava i obveze miruju od tog trenutka te se također može unaprijed odrediti visina naknade ili postupak (metoda) kojim će se taj iznos moći jednostavno utvrditi. ${ }^{47}$ Može se urediti i pitanje o tome kako će društvo raspolagati $\mathrm{s}$ tim poslovnim udjelom. Kod dvočlanih društava nerijetko postoje klauzule u društvenom ugovoru kojima se predviđa da, u slučaju istupa jednog člana, drugi član preuzima taj poslovni udio. Međutim, društvenim ugovorom ne smije se na nedopustiv način ograničiti pravo člana na istup. ${ }^{48}$

\section{2. Naknada}

Zaprimanjem izjave o istupu, društvo je dužno provesti postupak i pobrinuti se da se članu koji istupa plati naknada ili da se pronađe treća osoba koja će uz naknadu preuzeti te poslovne udjele. Zahtjev za isplatu naknade dospijeva $\mathrm{u}$ trenutku raspolaganja s poslovnim udjelom. Od tada se izračunavaju visina naknade i svi rokovi u svezi s tim zahtjevom. ${ }^{49}$ Ako društvo ne poduzme nijednu od mjera raspolaganja s poslovnim udjelom, član ih treba još jedanput pisanim putem, uz navođenje roka, pozvati da provedu postupak istupa do kraja. Član može već i u izjavi o istupu naznačiti taj rok. Dužnici su društvo i stjecatelj bez obzira na to prenosi li se poslovni udjel na ostale članove ili na treće osobe, a oni članu koji istupa odgovaraju solidarno i neograničeno za ispunjenje te obveze. ${ }^{50}$ Kao i u slučaju isključenja, treba uzeti u obzir tržišnu vrijednost poslovnog udjela. To je ona vrijednost koja uključuje stvarnu vrijednost udjela i vrijednost koja proizlazi iz očekivanja budućeg udjela u dobitku društva. Pod stvarnom vrijednošću podrazumijeva se ona vrijednost koja bi

47 Strohn, L., o. c. u bilj. br. 8., § 34, Rn. 203.

48 Rosner, $C$., „Streitvermeidung beim Austritt von GmbH-Gesellschaftern“, Vol . 40, ZGR, br. 6 (2011.), str. 737. i dalje.

49 U slučaju kad sud dopusti istupanje člana iz društva, pri odluci o isplati tržišne vrijednosti poslovnog udjela mora voditi računa o stanju društva i o njegovim poslovnim potrebama. Vidi presudu Visokog trgovačkog suda RH od 22. veljače 2012., Pž - 6944/2011, Informator, broj 6353 (2015.), str. 4.

${ }^{50}$ U literaturi zanimanje izaziva presuda njemačkog Vrhovnog suda (BGH) od 24. I. 2012. - Az. II ZR 109/11, dostupna na https://openjur.de/u/332999.html, pregledano 12. IX. 2016. Sud zauzima stav da u slučaju povlačenja udjela, ako društvo ne može isplatiti naknadu, ostali članovi supsidijarno odgovaraju za tu isplatu i to razmjerno svojim poslovnim udjelima u društvu. Spomenuto rješenje uopće nema uporište de lege lata. Lutter, M., o. c. u bilj. br. 5., § 34 Anh. Rn. 75. 
pripala članu društva ako bi društvo bilo likvidirano u trenutku isplate te naknade. Stvarna vrijednost društva razlika je između zbroja aktive i obveza društva, a stvarna vrijednost udjela odgovarajući je dio te razlike izračunan prema omjeru temeljnog uloga člana koji istupi iz društva odnosno člana koji je iz društva isključen i temeljnog kapitala društva. Ta se naknada može odnositi samo na tržišnu, a ne i na knjigovodstvenu vrijednost poslovnog udjela. Datum od značaja za procjenu vrijednosti nije datum povlačenja ili prijenosa poslovnog udjela nego datum kada je društvo zaprimilo izjavu o istupu..$^{51}$ To je i logično jer je toga dana član očitovao svoju volju pa nije opravdano očekivati da ga se veže za neki drugi datum koji nije sam odredio.

Društvenim ugovorom moguće je na različite načine urediti pitanje isplate naknade (primjerice obročna isplata) kao i njenu visinu. Ipak, bez učinka su odredbe društvenog ugovora kojima se naknada određuje u neprimjereno niskom iznosu u odnosu na tržišnu vrijednost pa bi time član koji istupa pretrpio znatan gubitak. Takvom se odredbom članu praktički onemogućuje da istupi iz društva. Postoji i široka siva zona, stoga za slučaj kada je društvenim ugovorom predviđen niži iznos naknade u odnosu na tržišnu cijenu, uvijek treba uzeti u obzir sve okolnosti konkretnog slučaja. Tako treba uzeti u obzir i razlog koji je doveo do istupa. Ako do istupa dolazi zbog izmjene društvenog ugovora ili zlouporabe vladajućeg položaja na štetu manjinskog člana društva, članu bi pripadalo pravo na viši iznos naknade nego u slučaju kada razlog za istup leži u osobi člana jer u ovom drugom slučaju valja zaštititi interese društva. Odredba kojom se ograničava iznos naknade bit će načelno dopuštena ako je riječ o redovitom pravu na otkaz.

Ako postoji dobra volja svih članova, tada neće biti potrebna sudska intervencija. No ako društvo u primjerenom roku po primitku izjave o istupu člana ne poduzme ništa s njegovim udjelom niti mu isplati naknadu, član će svoje interese morati zaštititi sudskim putem. ${ }^{52}$ Ako društvo odbije istup uz obrazloženje da nije nastupio opravdan razlog ili načelno prihvati izjavu ali odgodi raspolaganje udjelom i isplatu naknade, član može ustati s tužbom za isplatu naknade, a tijekom postupka sud će utvrditi je li nastao opravdan razlog za istup. ${ }^{53}$ Time se osigurava pravna zaštita

51 Fastrich, L., o. c. u bilj. br. 13., § 34 Anh. Rn. 25.

52 Tako se u presudi Visokog trgovačkog suda RH od 22. veljače 2012., Pž - 6944/2011, navodi da je Sud uvijek dužan ispitati postoje li propisani razlozi za istupanje člana iz društva te je to dužan učiniti i u slučaju kad protivna strana priznaje činjenice na kojima tužitelj temelji tužbu radi istupanja iz društva. Njegova je obveza bila i ispitati opravdavaju li tužiteljevo istupanje iz društva upravo oni razlozi na koje se tužitelj poziva. (...) Iz obrazloženja pobijane presude vidljivo je da pryostupanjski sud uopće nije utvrdio (niti naveo) koji je razlog tužiteljeva istupanja iz tuženikova društva. Štoviše, iz obrazloženja pobijane odluke proizlazi da sud uopće nije ni ispitivao postoje li opravdani razlozi za istupanje propisani odredbom članka 420. stavak 2. ZTD-a, već je pobijanu odluku temeljio na ocjeni da je tuženik priznao postojanje razloga za tužiteljevo istupanje iz njegova društva. (...). Informator, broj 6262 (2014)., str. 4.

53 Seibt, C., o. c. u bilj. br. 25., § 34 Anh. Rn. 21. Za razliku od ispitivanja razloga za istupanje iz društva kod kojih je mjerodavno vrijeme zaključenja glavne rasprave, za određivanje vrijednosti poslovnog udjela mjerodavno je vrijeme podnošenja tužbe (ako o istupanju odlučuje sud). Prilikom donošenja odluke o istupanju člana iz društva, sud mora odrediti i rok u kojem je društvo dužno članu koji istupa isplatiti tržišnu vrijednost njegova poslovnog udjela vodeći pri tome brigu o stanju društva i njegovim poslovnim potrebama jer prekratko određen rok može (ali i ne mora) dovesti do pogoršanja gospodarskog stanja 
društva. Društvo može pričekati da član ustane s tužbom i tada iznijeti prigovore. U tom postupku društvo ima i pravo zadržanja poslovnog udjela. U procesnom smislu, čini se da tužbeni zahtjev za isplatom naknade ne smije sadržavati i nalog da društvo poduzme mjeru raspolaganja tim poslovnim udjelom. Stoga ako sud usvoji tužbeni zahtjev člana na isplatu naknade a društvo i dalje odbija raspolagati poslovnim udjelom, članu koji istupa preostaje samo da ustane s novom tužbom tužbom za prestanak društva. Okolnost da je društvo odbilo raspolagati poslovnim udjelom predstavlja važan razlog koji bi sud trebao prihvatiti i donijeti odluku o prestanku društva. Spomenutom tužbom za prestanak društva član se može koristiti odmah ako je vidljivo da mu društvo ne smije isplatiti naknadu, a zbog odredaba o održanju kapitala društva. ${ }^{54}$ Kao i kod tužbe za isključenje člana, može se ugovoriti nadležnost arbitraže za spor o pretpostavkama i pravnim učincima istupa.

\section{ZAKLJUČAK}

Nesporno je da prema temeljnim načelima trgovačkog statusnog prava koje je kod nas pretočeno u zakonske odredbe (čl. 420. i 421. Zakona o trgovačkim društvima, u nastavku: ZTD) član društva ima pravo na istup iz društva čak i onda kada to nije posebno uređeno u društvenom ugovoru, što znači da načelno može tako postupiti suprotno volji ostalih članova. Pravo na istup jest neotuđivo osobno pravo svakog člana koje proizlazi i iz općeg pravnog načela da se svaki trajniji pravni odnos može okončati ako za to postoji opravdan razlog. Zbog toga spomenuto pravo nije moguće isključiti ili ograničiti već samo proširiti.

Iako član ima pravo na istup, njegova je dužnost poduzeti sve što je u njegovoj moći da prenese svoj poslovni udio na novog imatelja koji ce mu za to isplatiti dogovorenu naknadu. Kod prijenosa udjela nekog d.o.o.-a treba obratiti pozornost na nekoliko činjenica: prvo, ne postoji uređeno tržište za poslovne udjele kao što je to slučaj s dionicama; drugo, prijenos udjela nerijetko je otežan i zbog međusobnog odnosa članova (nesuglasje). Zbog toga ta „teoretska“ mogućnost raspolaganja udjelom ne predstavlja uvijek pravedno rješenje pa se ravnoteža uspostavlja odredbama o pravu člana na istup iz društva.

Za istup člana iz društva moraju se ispuniti tri pretpostavke: prvo, mora postojati opravdan razlog zbog kojeg se više ne može očekivati da član ostane u društvu pri čemu treba uzeti u obzir sve okolnosti slučaja; drugo, ne smije postojati blaže pravno sredstvo kojim član može ostvariti cilj (supsidijarna narav prava na istup) i treće, društvo mora imati sredstva dostatna za isplatu naknade članu koji istupa, u skladu s načelom održanja kapitala društva.

društva. Vidi presudu VTS od 1. VII. 2008., Pž-7151/05, dostupnu na http://www.iusinfo.hr, pregledano 12. IX. 2016.

54 Grünewald, B., „Probleme bei der Aufbringung der Abfindung für ausgetretene GmbHGesellschafter", GmbHR, br. 5 (1991.), str. 187. 
Pretpostavke koje predstavljaju opravdan razlog za istup mogu se podijeliti u tri grupe slučajeva. U prvu grupu slučajeva spadaju strukturne promjene kojima se znatno mijenjaju odnosi u društvu, u drugu spadaju slučajevi koji se vezuju uz ostale članove društva, a u treću slučajevi koji su u svezi s osobom člana koja istupa iz društva.

Istup zbog važnog razloga bit će dopušten samo onda kada ne postoji blaže pravno sredstvo koje bi član mogao koristiti u konkretnom slučaju. Stoga član koji namjerava istupiti iz društva prvo mora pokušati provesti pravni posao kupoprodaje poslovnog udjela, a pri tome je dužan prihvatiti i razuman gubitak - pad vrijednosti svoga poslovnog udjela. Naime, pravo člana na istup nikako ne smije postati sredstvo kojim će član rizik pada vrijednosti poslovnog udjela prebaciti na društvo i ostale članove.

Postupak istupa provodi se u dvije faze: član daje izjavu o istupu, a potom društvo mora provesti ostale radnje. Kada društvo zaprimi izjavu o istupu počinju teći rokovi za isplatu naknade članu te za raspolaganje poslovnim udjelom, ali u pravilu član zadržava svoja članska prava sve dok je imatelj poslovnog udjela u društvu. Član ima interes zadržati članski status dok se ne razriješi pitanje iznosa naknade. Društvenim ugovorom moguće je na različite načine urediti pitanje isplate naknade (primjerice obročna isplata) kao i njenu visinu. Ipak, bez učinka su odredbe društvenog ugovora kojima se naknada određuje u neprimjereno niskom iznosu u odnosu na tržišnu vrijednost poslovnog udjela.

\section{Literatura:}

1. Barbić, J., Pravo društava - društva kapitala, Sv. II., 5. izdanje, Organizator, Zagreb, 2010 .

2. Baumbach/Hueck, „Gesetz betreffend die Gesellschaften mit beschränkter Haftung“, 20. Auflage, Verlag C.H. Beck, München, 2013.

3. Roth, G./Altmeppen, H., „Gesetz betreffend die Gesellschaften mit beschränkter Haftung“, 7., Neubearbeitete Auflage, Verlag C. H. Beck, München, 2012.

4. Eschenlohr, H., „Beschränkungen der Austritts- und Kündigungsmöglichkeiten des Gesellschafters einer Familien-GmbH“, Festschrift fur Walter Sigle, OVS Verlag, Köln, 2000, str. 131. i dalje.

5. Fleischer, H./Goette, W., Münchener Kommentar zum Gesetz betreffend die Gesellschaften mit beschränkter Haftung, Verlag C. H. Beck, München, 2016.

6. Gorenc, V. et al., Komentar Zakona o trgovačkim društvima, IV. izdanje, RRiF, Zagreb, 2008.

7. Grünewald, B., „Probleme bei der Aufbringung der Abfindung für ausgetretene GmbH-Gesellschafter“, GmbHR, br. 5 (1991), str. 185. i dalje. 
8. Kallmeyer, H., ,Schutz vor Übernahmen in der GmbH“, GmbHR, br. 14 (2001.), str. 745. i dalje.

9. Lutter, M. /Hommelhoff, P., GmbH-Gesetz Kommentar, Verlag Otto Schmidt, Köln, 2012.

10. Rosner, C., „Streitvermeidung beim Austritt von GmbH-Gesellschaftern“, Vol . 40, ZGR, br. 6 (2011.), str. 732. i dalje.

11. Röhricht, V., Zum Austritt des Gesellschafters aus der GmbH, FS Alfred Kellermann, Berlin, de Gruyter, 1991., str. 361. i dalje.

12. Schindler, H., Das Austrittsrecht in Kapitalgesellschaften, C. H. Beck, München, 1999.

13. Scholz, „GmbHG: Kommentar zum GmbH-Gesetz“, 11. Auflage, Verlag Otto Schmidt, Köln, 2012.

14. Slakoper, Z., „Društvo s ograničenom odgovornošću“, Računovodstvo i financije, Zagreb, 2001.

15. Wellhöfer, W., „Ausscheiden eines GmbH-Gesellschafters in der Gesellschaftspraxis“, GmbHR, br. 4 (1994.), str. 212. i dalje.

16. Ziemons, H./Jaeger, C., Beck'scher Kommentar GmbHG, 28. Edition, Verlag C. H. Beck, München, 2016.

\section{EXIT FROM THE LIMITED LIABILITY COMPANY}

It is indisputable that members of Limited Liability Companies have the right to step out from the company even when it is not specifically regulated in the social contract. It means that in principle they can do that as the act of their own will, sometimes contrary to the will of the other members. The right to step out from the company is an inalienable personal right of every member. That right stems from the general legal principle that any permanent legal relationship may end if there's a legitimate, justified reason. The above mentioned right cannot be excluded or limited, but can only be expanded.

Although the member has the right to step out, it is his primary responsibility to take everything in his power to transfer his business share to the new holder and to use the right to step out from the company only as a subsidiary solution. When transferring shares of the company one should pay attention to several facts: first, there is no regulated market for the shares of the LLC such as is the case with stocks; secondly, the transfer of shares is often difficult because of the relationship between members of the company so the potential buyer sometimes steps into the unknown situation. Therefore, this "theoretical" possibility to dispose of the share is not always a just solution so the Lawmaker returns the balance with the provisions on the right of members to step out from the company.

The process, which will end with the elimination of the member from the company, must meet three preconditions: first, there must be a legitimate reason when it is not reasonably to expect that the member will remain in the company, taking into account all the circumstances of the case; 
Dr. sc. Ratko Brnabić i Bojan Brkić: Pluralitet ciljeva stečajnog postupka Zbornik radova Pravnog fakulteta u Splitu, god. 54, 3/2017., str. 615.- 636.

secondly, there should be no milder legal remedy whereby a member can achieve the goal and third, the company must have sufficient funds for this transaction, considering the principle of maintaining the company's capital.

Keywords: Exit from the Company, Exclusion, Withdrawal of business shares, Compensation, Capital Companies. 